\title{
小規模認可保育所を対象とした COUNTERMEASURE AGAINST 畳付収納家具による重量床衝撃 音対策方法に関する基礎的検討 HEAVY-WEIGHT FLOOR IMPACT SOUND BY STORAGE FURNITURE WITH TATAMI FOR SMALL-SCALE NURSERY SCHOOLS
}

$\begin{array}{ll}\text { 冨田隆太 }-* 1 & \text { 岡庭拓也 }-* 2 \\ \text { 大瀧友多— } * 3 & \text { 阿部今日子—— }\end{array}$

キーワード

重量床衝撃音，小規模認可保育所，防振，遮音

Keywords:

Heavy-weight floor impact sound, Small-scale nursery schools, Vibration control, Sound insulation

Ryuta TOMITA
Yuta OTAKI-

Takuya OKANIWA- $* 2$
Kyoko ABE $-* 4$

Small-scale authorized nursery schools are receiving recognition as a promising solution to the problem of long waitlists for nursery schools. It was measured the amount of reduction in floor impact sound pressure level caused by the car-tire source using a reverberation room with upper and lower floors. It was possible to improve the performance of the amount of reduction in the floor impact sound pressure level by a maximum of $14 \mathrm{~dB}$ in the $63 \mathrm{~Hz}$ octave band when using pieces of storage furniture with tatami on top by using appropriate vibration control measures and sound insulation measures.

\section{1.はじめに}

2015 年 4 月「子ども・子育て支援新制度」 ${ }^{1)}$ の施行に伴い， 小規 模認可保育所は, 都市部では待機児童問題解決の切り札として, 地 方では人口減少時代の新たな保育形態の雛型として期待されている。 小規模認可保育所は, 0 歳から 2 歳までの子どもを対象に, 定員規 模 6 人以上 19 人以下でも開設できるようになり, マンションの空 き室やビルの一室などの比較的面積が小さい場所でも, 保育所を開 設できるようになった。

さらに, 2017 年 6 月には特区法成立により, 小規模認可保育所に おける対象年齢が 5 歳まで拡大された ${ }^{2)}$ 。2 歳までの乳幼児と異な り, 体力の向上により運動量も増すことが予想される。また, 体重 の増加に伴い, マンション内に開設するとなると, 子供の声 (空気 音）だけでなく，床衝撃音の対策がとても重要な課題となってくる ことが推測される。

そこで, 本研究では小規模認可保育所を対象として, 重量床衝撃 音の対策方法について検討を行った。なお, 小規模認可保育所では, 設置期間が短いケースや, 予算も限られている場合もあることから， より短期間・低予算で重量床衝撃音対策を行える可能性を検討する ため, 市販品 (畳付収納家具) を用いて, 重量床衝撃音レベル低減 量の効果が得られるかの基礎的検討を行った。また, 畳付収納家具 を用いた理由としては，用途変更により，保育所において不足する 可能性がある収納を少しでも確保したいということ, また数年後に
保育所が充足され，他の用途に変更寸る際に，撤去が容易にできる ということも挙げられる。

本報の範囲は, 単体の畳付収納家具を床に設置したときに重量床 衝撃音レベル低減量をどのように向上させるかについて, 防振, 遮 音, 吸音の視点から検討したものである。また，本研究は小規模認 可保育所を対象として, 床構造・床仕上げ構造を変化することなく, その上に畳付収納家具を設置して重量床衝撃音対策を行っていこう と寸るものであり，このような研究は既往研究では見当たらない。

本報ではコンクリートスラブ素面を対象に, 盢付収納家具を設置 したときの重量床衝撃音の対策について基礎的検討を行った。

\section{2. 実験方法}

\section{1 実験施設}

実験は，上下階残響室 (建材試験センター)を用い，標準重量床衝 撃源による床衝撃音レベル低減量の測定を JIS A 1440-2 に準拠して 行った。

図 1 (左 : 音源室, 右 : 受音室)に平面図及び加振点及び受音点を 示す。加振点は中央の 1 点とし, 受音点は 5 点とした。加振は, JIS A 1418-2 の衝撃力特性(1)のタイヤで行った。タイヤの落下高さは $85 \mathrm{~cm}$ とした。加振点 1 点の理由は, 本研究では最大 $600 \mathrm{~mm} \times 900 \mathrm{~mm}$ 程度の畳付収納家具上での加振を行ったことによる。

畳付収納家具については, JIS A 1440-2 の試料の分類によれば,

\footnotetext{
本報告は, 日本音響学会 2019 年春季研究発表会 ${ }^{3) ~ 4)}$, INTER-NOISE $2019^{5)}$ に加えて分析を行い，加筆及び再構成したものである。

日本大学理工学部建築学科 教授・博士 (工学)

( ( 101-8308 千代田区神田駿河台 1-8-14)

戸田建設(侏) / 日本大学大学院理工学研究科 研究生・修士（工学）

Prof., Dept. of Architecture, College of Science and Technology, Nihon Univ., Dr. Eng.

2 Toda Corp. / Research Student, Graduate School of Science and Technology, Nihon Univ., M. Eng.

建材試験センター 修士 (工学)

フリーランス 博士（工学）

Japan Testing Center for Construction Materials, M. Eng.

Freelance Researcher, Dr. Eng.
} 
その連結方法にもよるが, カテゴ リーIIが想定される。但し, 本報 ではまず基礎的検討として, 単体 のみを対象とした。そのため, 小 面積となり，カテゴリーI を想定 して行ったため, コンクリート製 標準床で仕切った 2 室をもつ試験 装置で行った。さらに, 盢付収納 家具の位置を 5 点移動すれば, 加 振点ごとの低減量がわかるが，本 報では基礎的検討として, 単体の 畳付収納家具を床に設置したとき に, 重量床衝撃音レベル低減量が どのように変化するかについて複 数のパターンにより検討を行った。

受音点には, 図 1 に示す L1〜 L5 に騷音計（RION，NL-42) を設置し た。マイクロホンの高さは, 戝に 記載の通りである。図 2 に, 床ス ラブの断面を示す。コンクリート床の厚さは $150 \mathrm{~mm}$ であった。

\section{2 実験施設}

図 3 に, 畳付収納家具の試験体を示す。図中の a, b は加振点を示 す。試験体は, A〜C の 3 パターンとした。試験体 A のサイズは, 600 $\times 600 \times H 450 \mathrm{~mm}$ (内寸 $560 \times 560 \times \mathrm{H} 410 \mathrm{~mm}$ ) であり, 質量は $10 \mathrm{~kg}$ で ある。試験体 B のサイズは, 試験体 A の高さが低くなったもので, $600 \times 600 \times H 315 \mathrm{~mm}$ (内寸 $560 \times 560 \times H 280 \mathrm{~mm}$ ) であり, 質量は $8 \mathrm{~kg}$ である。試験体 C のサイズは, 試験体 A の一辺の サイズが大きくなったもので, $900 \times 600 \times H 450$ $\mathrm{mm}$ (内寸 $420 \times 560 \times H 410 \mathrm{~mm} \times 2$ ヶ所)であり，質量 は $15 \mathrm{~kg}$ である。試験体 C は, 収納部分の間に垂 直方向に仕切り板がある。側板と仕切り板はビス 留めであるが, 隙間はほとんどない。また, 仕切 り板は側板と同様に，天板と接触している。

表 1 に, 実験を行った 25 パターンの概要を示す。 実験 No. 1 は, コンクリートスラブ素 面とした。畳付収納家具については, 天板の畳板は，プリント紙化粧繊維 板十ポリプロピレンの基材上に，天 然い草で表面を覆った仕様で, $20 \mathrm{~mm}$ の厚さである。繊維板が天板の下部 にあるため，通気性はない。また， 天板裏側に側板とずれが生じないよ うに, ストッパー(繊維板, 幅 $15 \mathrm{~mm}$, 厚さ $9 \mathrm{~mm}$ )がついている。なお，側 板と天板の隙間はほとんどない。ま た, 畳付収納家具の内部に質量を負 荷させる場合に，耐荷重を大きくす るために, 底部をラワン合板で補強 した仕様も表に示寸通りである。な お, 疊付収納家具は, 底部を補強し
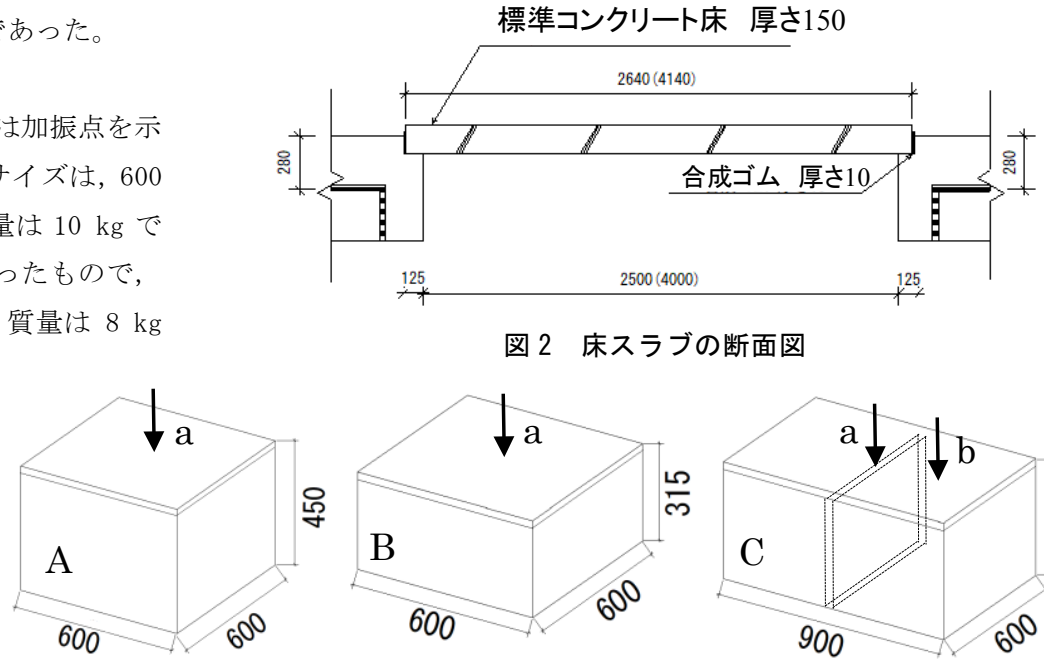

図 2 床スラブの断面図

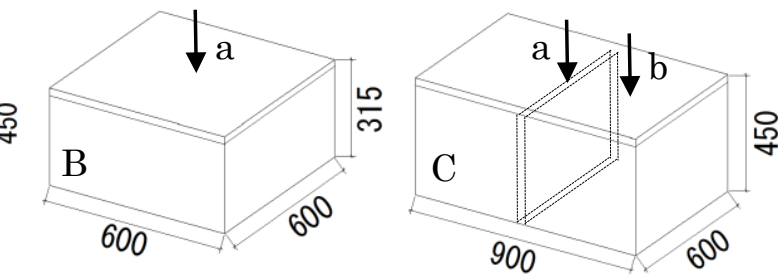

図 3 畳付収納家具と加振点

表 1 試験体概要

\begin{tabular}{|c|c|c|c|c|c|c|c|c|c|c|}
\hline & 試験体 & 家具サイズ(mm) & $\begin{array}{l}\text { 家具重 } \\
\text { 量 }(\mathrm{kg})\end{array}$ & $\begin{array}{l}\text { 質量付 } \\
\text { 加 }(\mathrm{kg})\end{array}$ & \begin{tabular}{|l|} 
底板補強 \\
合板 $(\mathrm{kg})$
\end{tabular} & $\begin{array}{c}\text { 総質量 } \\
\text { (kg) }\end{array}$ & $\begin{array}{c}\begin{array}{c}\text { 防振ゴムサイズ } \\
(\mathrm{mm})\end{array}\end{array}$ & 吸音材 & $\begin{array}{c}\text { 空気層(仕切り } \\
\text { 板を挿入) }\end{array}$ & 加振位置 \\
\hline 1 & 0 & - & - & - & - & - & - & - & - & a \\
\hline 2 & $A-1$ & $600 \times 600 \times 450$ & 10.0 & - & - & 10.0 & $200 \times 200 \times 12.5$ & - & - & $\mathrm{a}$ \\
\hline 3 & $A-2$ & $600 \times 600 \times 450$ & 10.0 & - & 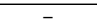 & 10.0 & $200 \times 200 \times 25$ & - & - & a \\
\hline 4 & $A-3$ & $600 \times 600 \times 450$ & 10.0 & - & $\begin{array}{ll}- \\
\end{array}$ & 10.0 & $200 \times 200 \times 25$ & 8層 $(500 \times 500 \times 50 / 1$ 層 $)$ & - & $a$ \\
\hline 5 & $A-4$ & $600 \times 600 \times 450$ & 10.0 & 34.0 & - & 44.0 & $200 \times 200 \times 25$ & - & - & a \\
\hline 6 & $A-5$ & $600 \times 600 \times 450$ & 10.0 & 68.0 & - & 78.0 & $200 \times 200 \times 25$ & - & - & a \\
\hline 7 & $A-6$ & $600 \times 600 \times 450$ & 10.0 & 68.0 & - & 78.0 & $100 \times 100 \times 50$ & - & - & a \\
\hline 8 & $A-7$ & $600 \times 600 \times 450$ & 10.0 & 68.0 & 2.3 & 80.3 & $100 \times 100 \times 50$ & - & - & $a$ \\
\hline 9 & $A-8$ & $600 \times 600 \times 450$ & 10.0 & 34.0 & 2.3 & 46.3 & $100 \times 100 \times 50$ & - & 2層(端部密閉) & $a$ \\
\hline 10 & $A-9$ & $600 \times 600 \times 450$ & 10.0 & 34.0 & 2.3 & 46.3 & $100 \times 100 \times 50$ & - & 2層(端部開放） & a \\
\hline 11 & $A-10$ & $600 \times 600 \times 450$ & 10.0 & 34.0 & 2.3 & 46.3 & $100 \times 100 \times 25$ & - & 2層(端部開放) & $a$ \\
\hline 12 & $A-11$ & $600 \times 600 \times 450$ & 10.0 & 34.0 & 2.3 & 46.3 & - & - & 2層(端部開放) & $\mathrm{a}$ \\
\hline 13 & $A-12$ & $600 \times 600 \times 450$ & 10.0 & - & 2.3 & 12.3 & $\begin{array}{ll}- \\
\end{array}$ & - & 2層(端部開放) & a \\
\hline 14 & $A-13$ & $600 \times 600 \times 450$ & 10.0 & - & 2.3 & 12.3 & - & $\begin{array}{c}\text { 4層(上下に各2層, } 500 \times \\
500 \times 50 / 1 \text { 層) }\end{array}$ & 2層(端部開放) & a \\
\hline 15 & A-14 & $600 \times 600 \times 450$ & 10.0 & - & 2.3 & 12.3 & - & - & - & a \\
\hline 16 & $A-15$ & $600 \times 600 \times 450$ & 10.0 & - & - & 10.0 & - & - & - & a \\
\hline 17 & B-1 & $600 \times 600 \times 315$ & 8.0 & 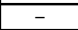 & $\overline{-1}$ & 8.0 & 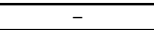 & $\overline{-1}$ & $\overline{-1}$ & $a$ \\
\hline 18 & B-2 & $600 \times 600 \times 315$ & 8.0 & 68.0 & 2.3 & 78.3 & $100 \times 100 \times 50$ & - & - & $a$ \\
\hline 19 & B-3 & $600 \times 600 \times 315$ & 8.0 & 34.0 & 2.3 & 44.3 & $100 \times 100 \times 50$ & 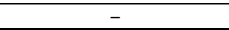 & 2層(端部開放） & $a$ \\
\hline 20 & $c-1$ & $900 \times 600 \times 450$ & 15.0 & - & - & 15.0 & - & - & - & $a$ \\
\hline 21 & $C-1$ & $900 \times 600 \times 450$ & 15.0 & - & - & 15.0 & - & - & - & $\mathrm{b}$ \\
\hline 22 & $c-2$ & $900 \times 600 \times 450$ & 15.0 & 34.0 & - & 49.0 & $100 \times 100 \times 50$ & - & - & $a$ \\
\hline 23 & $c-2$ & $900 \times 600 \times 450$ & 15.0 & 34.0 & - & 49.0 & $100 \times 100 \times 50$ & - & - & b \\
\hline 24 & $c-3$ & $900 \times 600 \times 450$ & 15.0 & 34.0 & - & 49.0 & $100 \times 100 \times 50$ & - & 2層(端部密閉) & a \\
\hline 25 & $c-3$ & $900 \times 600 \times 450$ & 15.0 & 34.0 & - & 49.0 & $100 \times 100 \times 50$ & - & 2層(端部密閉) & b \\
\hline
\end{tabular}


ていない場合は, 側板 (合板と合板の間に一部に芯材 あり, 総厚 $17 \mathrm{~mm}$ )の下部 (硬質ゴム付き, 長さ $80 \mathrm{~mm}$ ) と底板（合板 $4 \mathrm{~mm}$ ) は $14 \mathrm{~mm}$ の差がある。また, 底 板を補強している場合は, 側板と底板 (ラワン合板 $12 \mathrm{~mm}$ で補強, ビスで側板と固定)は， $2 \mathrm{~mm}$ の差があ る。いずれも, 底板の方が側板より高い位置にあり, 防振ゴムと接触しているのは側板の四隅となる。

本報では, 試験体の仕様変化による重量床衝撃音 レベル低減量を大きくするため, (1)防振, (2)遮音, (3)吸音を検討した。また，仕様変化については，前 述の通り，低予算と施工のしや寸さを考慮した。ま た, 試験体の高さは最大 $450 \mathrm{~mm}$ であるが, 保育所の ような子どもを対象とした空間であれば，身長から 見て, 天井高さの問題はないと考えた。

また，保育空間の断面計画を考察した稲葉ら ${ }^{6)} の$ 研究では,「断面空間により幼児の居場所が高い位置 に作られることで視認範囲が拡大し, 他者を把握し やすい交流のきっかけを生む場が作られる。」報告 されている。このことから, 保育空間の一部を利用 して, 畳付収納家具部分により, 高くなる空間を創造することは, 建築計画の視点では, 有効であると考えられる。

\section{3. 実験結果及び考察}

\section{1 コンクリートスラブ素面}

図 4 に, 素面の結果を示す。なお, 測定結果は, 前述したように, 加振点 1 点による受音点 5 点のエネルギー平均值とした。重量床衝 撃音レベル低減量は, JIS A 1440-2 では, 加振点 4 点以上 (5 点以上 が望ましい)で, 加振点ごとの受音点 4 点以上のエネ ルギー平均值を, 算術平均して求めるが, 本報では, 畳付収納家具単体の基礎的検討のため, 加振点 1 点 による受音点 5 点のエネルギー平均值で検討した。 コンクリートスラブ素面から試験体を設置した状態 の重量床衝撃音レベルを差し引いて, 重量床衝撃音 レベル低減量を求めた。なお，試験体はテープや接 着剤等は使用せず，コンクリートスラブ上に直置き 又は防振ゴム上に直置きした。暗騒音は等価音圧レ ベルを 10 秒測定した結果であり，63〜 500 Hz 帯域 で，33, 34, 33, $34 \mathrm{~dB}$ であった。

\section{2 防振対策}

防振対策を行うために, 防振ゴムを用いた。なお, 防振ゴムには, エーテル系の発泡ポリウレタン・エ ラストマー $\left(0.16 \mathrm{~g} / \mathrm{cm}^{3}\right)$ を用いた。防振ゴムの動的 バネ定数を算出するために, 表 1 の B-3 試験体を対 象にタイヤ加振による試験体の振動加速度を測定し た。振動加速度ピックアップを, 畳付収納家具の側 板一面の中央位置に取り付けた。スペクトル分析し た結果, $6.25 \mathrm{~Hz}$ が 1 次固有振動数であった。また, 低域のスペクトル特性は, 際立った共振を示すことなく, $30 \mathrm{~Hz}$ 程 度までブロードな特性を示していた。なお, 隣り合う側板にも加速 度ピックアップをとりつけ，同様な測定を行ったが，同様なスペク

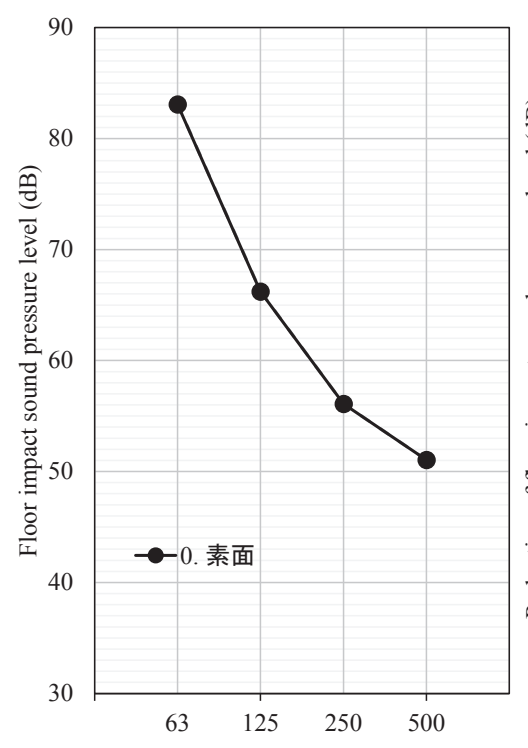

Octave band center frequency $(\mathrm{Hz})$

図 4 素面の床衝撃音レベル

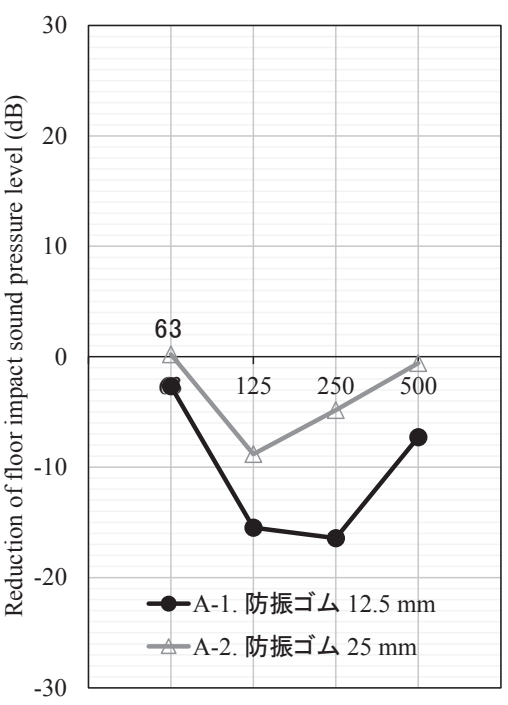

Octave band center frequency $(\mathrm{Hz})$

図 5 防振ゴムの厚さ変化

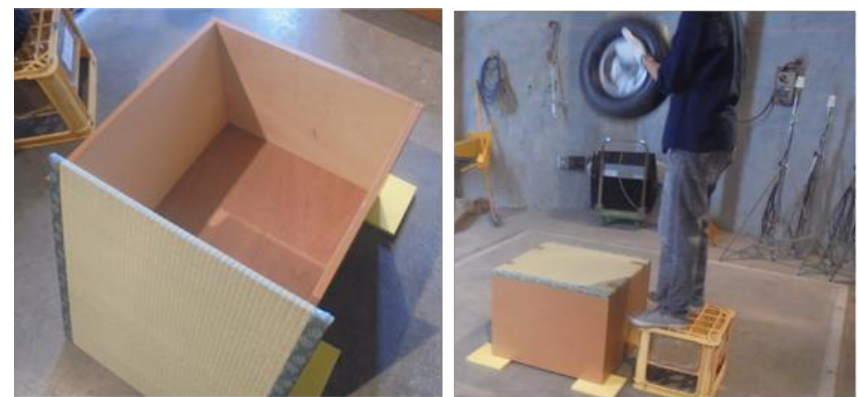

図 6 試験体と防振ゴムの設置

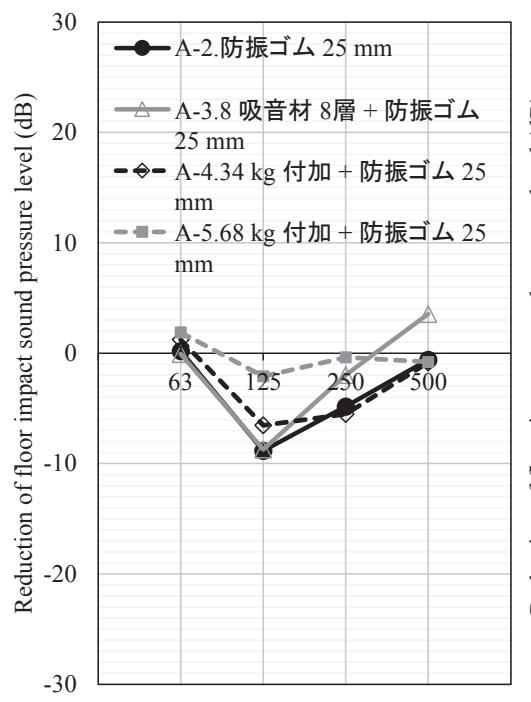

Octave band center frequency $(\mathrm{Hz})$

図 7 質量付加の変化

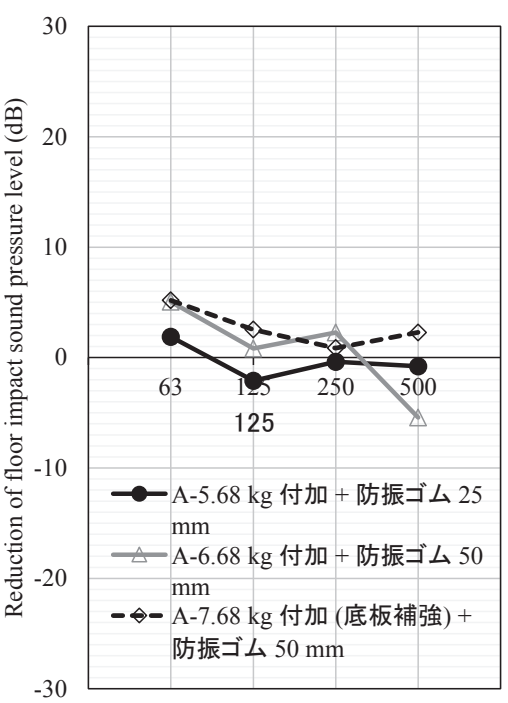

Octave band center frequency $(\mathrm{Hz})$
図 8 防振ゴムの厚さ変化 $(68 \mathrm{~kg}$ 付加 $)$
トル特性であった。また, 動的バネ定数を算出すると, $50 \mathrm{~mm}$ 厚の 防振ゴムで $1.7 \times 10^{4} \mathrm{~N} / \mathrm{m}$ であった。なお，この $50 \mathrm{~mm}$ 厚の防振ゴム は, 後述する表 2 で性能が良い試験体に使用した仕様であった。

図 5 に, 試験体 A-1, 2 の実験結果を示す。図 6 のように, 防振ゴ 
ムの上に試験体を設置した。なお，防振ゴムと試験 体の設置については, 図に示寸ように, 試験体 4 隅 に防振ゴムを配置し，かつ防振ゴムの $1 / 4$ の面積に 試験体が載るようにした。これは，今後の検討であ るが, 試験体を連続させることを考えて検討したた めである。図 5 を見ると, 素面と比べて 125〜 $250 \mathrm{~Hz}$ 帯域で共振増幅が見られ, $125 \mathrm{~Hz}$ 帯域では, コンク リートスラブ素面に対して， $-15 \sim-9 \mathrm{~dB}$ の值を示 しており, コンクリートスラブ素面よりも床衝撃音 レベルが大きくなった。

そこで, 防振効果を検討するために，質量を負荷 した。質量は, 畳付収納家具の底部に, アスファル 卜系制振シートを収納部分に隙間なく敷き詰めた。 制振シートの密度を測定すると, $2.5 \times 10^{3} \mathrm{~kg} / \mathrm{m}^{3}$ で あった。図 7 に, 試験体 A-2 2 の実験結果を示す。 A-2，4，5 のように, 質量を空の状態から，34 kg, $68 \mathrm{~kg}$ と収納部分に積載していくと，63〜250 Hz 帯 域で床衝撃音レベル低減量が大きくなる傾向が見ら れる。一方, A-2 のパターンで, 試験体 A の収納部 分を埋めるように, 吸音材(ポリエチレンテレフタレ

一ト繊維, $24 \mathrm{~kg} / \mathrm{m}^{3}$, 厚さ $50 \mathrm{~mm}$ ) を 8 層挿入した A-3 と比較すると, 重量床衝撃音を決定する $63 \mathrm{~Hz}$ 帯域, $125 \mathrm{~Hz}$ 帯域に変化はまったく 見られない。但し, $250 \mathrm{~Hz}, 500 \mathrm{~Hz}$ 帯域では 3〜 $4 \mathrm{~dB}$ 大きくなった。 以上から, 本研究のような畳付収納家具内での吸音効果は, 重量床 衝撃音には影響がないことがわかった。

図 8 には, 荷重 $68 \mathrm{~kg}$ を収納部分に積載した状態で, 防振ゴムの 厚さを変化させたパターンを示す。 $\mathrm{A}-5$ に比べて, 防振ゴムの厚さ を 2 倍の $50 \mathrm{~mm}$ に設置した A-6 のパターンでは, $63 \mathrm{~Hz}, 125 \mathrm{~Hz}$ 帯 域では $3 \mathrm{~dB}$ の低減量の向上が見られた。防振ゴムのバネ定数につい て, 理論上は厚さが 2 倍になれば $1 / 2$ になることから, 1 次固有振 動数が低下し，63〜 $125 \mathrm{~Hz}$ の低域では効果があったと推定される。 A-7 は, A-6 の底板耐荷重を増加させるために, 底板下に合板で補強 したパターンであるが, 床衝撃音レベル低減量は A-6 とほとんど変 化しないことを確認した。

\section{3 遮音対策}

本報で用いた試験体の中身は空洞（図 6)である。そのため，上部 を加振すると空気の内部音圧が発生し, 床衝撃音として下階に伝搬 する。この空気による音圧を制御するために, 試験体内部に, 仕切 り板としてラワン合板 $(12 \mathrm{~mm})$ を設置した。仕切り板の設置は, 床面 と平行に, 高さ方向の中央部分 (仕切り板底部が, A, C 試験体は底 部から $200 \mathrm{~mm}, B$ 試験体は底部から $150 \mathrm{~mm}$ ) とした。ラワン合板は, 試験体内部の 4 隅に角材 $(8 \mathrm{~mm}$ 角) を配置し, 接着剂等は使用せずに 角材上に置いた。試験体内部の空気層に仕切り板を挿入し, 2 層に することで遮音効果が得られるかどうかについて検討を行った。

図 9 に, 試験体 A-4,A-10 の結果を示寸。防振方法は同条件とし, 仕切り板挿入による空気層が 2 層か 1 層かの違いである。 $\mathrm{A}-10$ は, 仕切り板の端部を密閉せず, 隙間が $1 \mathrm{~mm}$ 程度生じている。結果を見 ると, 仕切り板の遮音効果により, $63 \mathrm{~Hz}, 125 \mathrm{~Hz}$ 帯域で $6 \mathrm{~dB}$ の性 能向上が見られた。次に, 図 10 に, 試験体 A-8, A-9 の結果を示す。 A-8, A-9 共に, 防振方法は同条件であり, 仕切り板の端部の条件の
違いについて検討を 行った。A-8 のよう に, 端部から空気が 抜けないようにガム テープで密閉するこ とで, 遮音性能が 63 $\mathrm{Hz}, 125 \mathrm{~Hz}$ 帯域で 4 $\mathrm{dB}$ の性能向上が見 られた。A-8は, 防 振及び遮音の両方の 対策を行い, $63 \mathrm{~Hz}$ 帯域で $14 \mathrm{~dB}$ の床衝 撃音レベル低減量で あった。

ここで, $14 \mathrm{~dB}$ 性 能をスラブ厚のみで 向上させるためには,

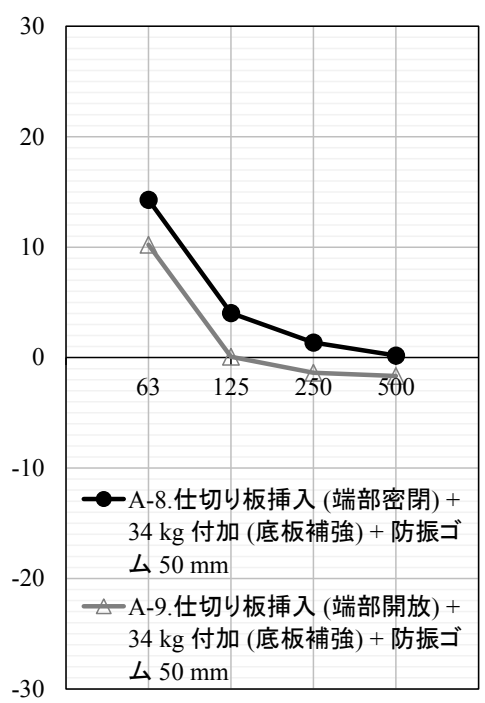

Octave band center frequency $(\mathrm{Hz})$

図 10 仕切り板の端部処理の変化

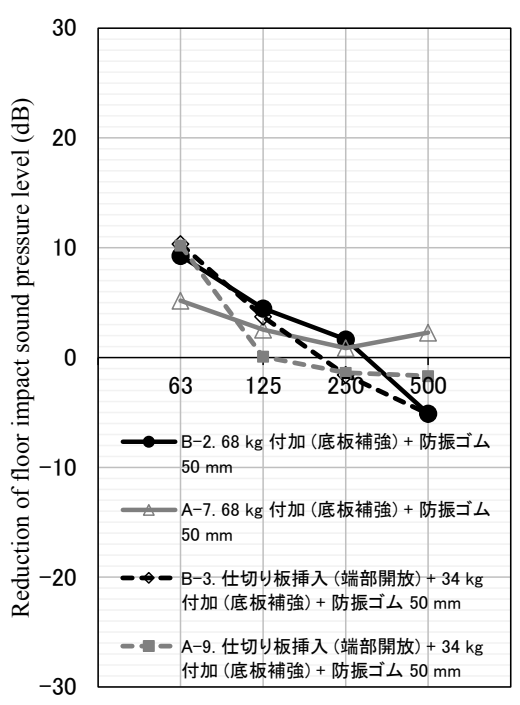

Octave band center frequency $(\mathrm{Hz})$

図 11 試験体 B とAの比較
スラブ厚を 2.24 倍, $150 \mathrm{~mm}$ の場合には $336 \mathrm{~mm}$ にする必要があり, A-8 は実用的な対策例であると考えられる。また, 図 9 の仕切り板 なしと仕切り板挿入 (端部開放) は $63 \mathrm{~Hz}$ 帯域で $6 \mathrm{~dB}$ の差, 図 10 の 端部開放の有無は $63 \mathrm{~Hz}$ 帯域で $4 \mathrm{~dB}$ の差であった。ゆえに, これら の効果が加算できると推定すれば, 仕切り板を挿入し, かつ端部処 理を密閉することで, 空洞状態に比べて防振方法が同条件であれば, $63 \mathrm{~Hz}, 125 \mathrm{~Hz}$ 帯域で $10 \mathrm{~dB}$ の床衝撃音遮断性能の向上が得られる 可能性がある。今後, さらに様々な条件下で検討を行い, より効果 的な仕様を検討していく必要性がある。

\section{4 畳付収納家具のサイズ变化の考察}

試験体 B の結果を試験体 A の結果と比較して示す。図 11 には, 試 験体 B-2 と A-7, B-3 と A-9 を比較して示す。B-2 と A-7 は, 試験体 そのものの質量は $2 \mathrm{~kg}$ 異なるが, 総質量から見れば, ほとんど変化 がない。しかしながら, $63 \mathrm{~Hz}, 125 \mathrm{~Hz}$ 帯域では 2〜4 dB, 試験体 
B-2 の方が床衝撃音レベル低減量は大きかった。次 に, B-3 と A-9 は, 防振十遮音対策を行った仕様で あり,この仕様でも, $63 \mathrm{~Hz}$ 帯域には変化が見られ ないが, $125 \mathrm{~Hz}$ 帯域では $4 \mathrm{~dB}$, 試験体 B-3 の方が 床衝撃音レベル低減量は大きかった。以上から, 試 験体 B のように, 高さを低くしても, $30 \mathrm{~cm}$ 程度あ れば, 今回の比較した仕様では, 重量床衝撃音を決 定することの多い，63，125 Hz 帯域では, 試験体 A に比べて, 同等かやや良い床衝撃音レベル低減量 を示すことがわかった。

次に, 試験体 C の結果を試験体 A の結果と比較し て示す。試験体 C の場合には, 平面の長辺方向のサ イズが $900 \mathrm{~mm}$ と長いため, 図 3 に示すように, 床面 に垂直に仕切り板が入っている。そのため, 加振点 は, 試験体中央の仕切り板上の a と収納部分 (空洞部 分)の中央のbとした。

図 12 には, 試験体 C-2 と A-4, A-6 を比較して示 す。C-2 と同様な仕様で実験を行った仕様がないた め, 近い仕様で比較した。A-4に比べて, A-6 はバネ 定数も小さく, 質量も大きいため, 低域に共振が生 じる仕様である。C-2 と同様な条件で, 試験体 A を 行えば，共振周波数は，A-4 と A-6 の間に生じると 予想される。C-2 の結果を見ると, 加振位置によら ず， 63〜 $125 \mathrm{~Hz}$ 帯域までの值は，A-4 と A-6 の間の 值を示した。また，C-2 の加振点の違いを見ると， 仕切り板を加振した方が, 空洞部分を加振するより も, 床衝撃音レベル低減量は大きい。図 13 には, 試 験体 C-3 と A-8 を比較して示す。 C -3 と A -8 は, 試 験体そのものの質量は $5 \mathrm{~kg}$ 異なる。また, 質量付加 は同じ $34 \mathrm{~kg}$ であるが, 試験体 C は, 空洞部分が 2 つあるため, 1 つの空洞には, $17 \mathrm{~kg}$ の質量負荷であ った。結果を見ると, A-8 と比べて, $63 \mathrm{~Hz}$ 帯域で床 衝撃音レベル低減量が $11 \mathrm{~dB}$ 小さかった。この違い については, 前述したように, 空洞部分が連続して いる仕様であり,かつ, 空洞部分のサイズが異なる。 今後, 同じサイズの空洞部分で連続している仕様も 含め, 更に実験的検討を行っていく予定であり, 今 後の課題としたい。

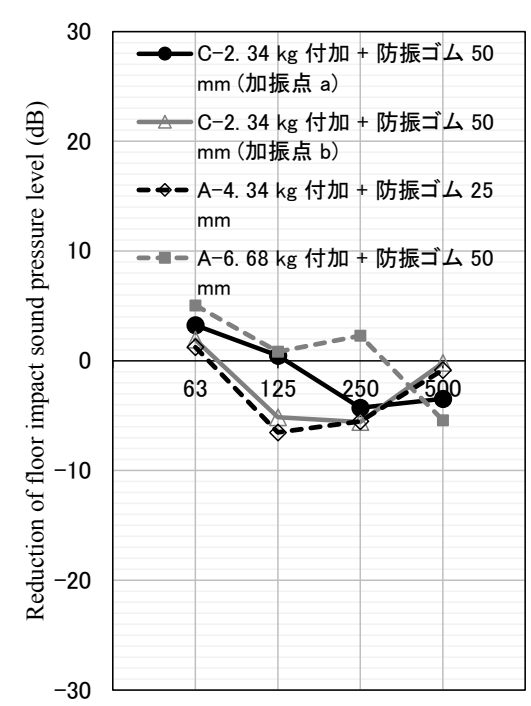

Octave band center frequency $(\mathrm{Hz})$

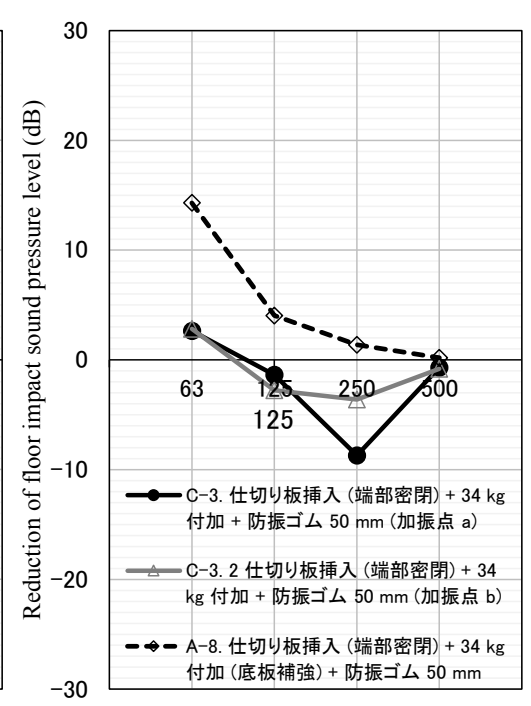

Octave band center frequency $(\mathrm{Hz})$

図 13 試験体 CとAの比較 (仕切り板)

表 2 実験結果一覧

\begin{tabular}{|c|c|c|c|c|c|c|c|c|}
\hline \multirow{2}{*}{ 実験No. } & \multirow{2}{*}{ 試験体 } & \multirow{2}{*}{ 加振点 } & \multicolumn{5}{|c|}{ 床衝撃音レベル低減量 (dB) } & \multirow{2}{*}{$\begin{array}{c}63 \mathrm{~Hz} \text { 低減量 } \\
\quad(\mathrm{dB})\end{array}$} \\
\hline & & & $31.5 \mathrm{~Hz}$ & $63 \mathrm{~Hz}$ & $125 \mathrm{~Hz}$ & $250 \mathrm{~Hz}$ & $500 \mathrm{~Hz}$ & \\
\hline 9 & $A-8$ & $a$ & 9.4 & 14.3 & 4.0 & 1.4 & 0.2 & $11 \sim 15$ \\
\hline 19 & B-3 & $a$ & 7.1 & 10.3 & 3.7 & -1.6 & -5.1 & \multirow{4}{*}{$6 \sim 10$} \\
\hline 10 & A-9 & $a$ & 7.3 & 10.2 & 0.1 & -1.4 & -1.7 & \\
\hline 18 & $\mathrm{~B}-2$ & $\mathrm{a}$ & 6.2 & 9.3 & 4.5 & 1.7 & -5.1 & \\
\hline 11 & $A-10$ & $a$ & 4.9 & 6.8 & -1.0 & -2.6 & 0.2 & \\
\hline 16 & $A-15$ & $a$ & 4.4 & 5.3 & -15.3 & -17.0 & -16.9 & \multirow{15}{*}{$1 \sim 5$} \\
\hline 8 & $A-7$ & a & 5.0 & 5.2 & 2.5 & 0.9 & 2.3 & \\
\hline 7 & $A-6$ & $a$ & 4.2 & 5.0 & 0.8 & 2.3 & -5.4 & \\
\hline 17 & B-1 & a & 3.8 & 5.0 & -16.4 & -14.3 & -14.9 & \\
\hline 15 & A-14 & $a$ & 5.9 & 4.8 & -18.2 & -18.5 & -18.9 & \\
\hline 21 & $C-1$ & $b$ & 2.6 & 4.2 & -13.6 & -15.0 & -15.9 & \\
\hline 14 & $A-13$ & $a$ & 5.4 & 4.0 & -14.5 & -17.2 & -19.7 & \\
\hline 12 & $A-11$ & a & 5.1 & 4.0 & -17.3 & -14.4 & -14.6 & \\
\hline 13 & $A-12$ & $a$ & 4.8 & 3.5 & -16.7 & -17.7 & -18.8 & \\
\hline 22 & C-2 & $a$ & 3.4 & 3.2 & 0.5 & -4.3 & -3.5 & \\
\hline 25 & $C-3$ & $\mathrm{~b}$ & 5.4 & 2.8 & -2.8 & -3.6 & -0.8 & \\
\hline 24 & $C-3$ & $a$ & 3.7 & 2.7 & -1.4 & -8.7 & -0.7 & \\
\hline 23 & $C-2$ & b & 4.8 & 1.9 & -5.1 & -5.6 & -0.2 & \\
\hline 6 & $A-5$ & $a$ & 3.1 & 1.9 & -2.1 & -0.4 & -0.8 & \\
\hline 5 & $\mathrm{~A}-4$ & a & 2.4 & 1.2 & -6.5 & -5.5 & -0.8 & \\
\hline 3 & $A-2$ & $a$ & 1.5 & 0.2 & -8.8 & -4.8 & -0.6 & \multirow{5}{*}{$-4 \sim 0$} \\
\hline 20 & $C-1$ & $\mathrm{a}$ & 0.3 & 0.1 & 1.1 & -2.7 & -2.0 & \\
\hline 1 & 0 & $\mathrm{a}$ & 0.0 & 0.0 & 0.0 & 0.0 & 0.0 & \\
\hline 4 & $A-3$ & $a$ & 1.3 & -0.1 & -8.7 & -2.0 & 3.5 & \\
\hline 2 & $A-1$ & $a$ & 1.1 & -2.7 & -15.5 & -16.4 & -7.3 & \\
\hline
\end{tabular}

とで, A-8 程度の性能が実現できると考えられる。前述したように, コンクリートスラブ素面 $150 \mathrm{~mm}$ の重量床衝撃音対策を, 床スラブ厚 のみで $14 \mathrm{~dB}$ 向上させるためには, スラブ厚を 2.24 倍, すなわち $336 \mathrm{~mm}$ にする必要がある。その点を考えれば，本報のように，コン クリートスラブから高さを, 最大 $50 \mathrm{~cm}$ 程度上げた試験体を設置し ても, 子どもの身長 (5 歳, $\left.110.3 \mathrm{~cm}^{7}\right)$ を考えれば, 実用的な対策 となりうると考えられる。

次に, $63 \mathrm{~Hz}$ 帯域の床衝撃音レベル低減量で, 5〜10 dB であった 仕様は, 8 仕様であった。この内, 試験体 A は 5 仕様あったが、防 振ゴム $50 \mathrm{~mm}$ の仕様であれば, 遮音対策をしなくても, 床衝撃音レ ベル低減量で $5 \mathrm{~dB}$ 以上が可能であると考えられる。すなわち, 収納 として利用できるスペースが大きいことが利点と考えられる。なお， たように同程度の結果であったことから，B-3 の端部を密閉するこ 
前述したように, $50 \mathrm{~mm}$ 厚の防振ゴムの動的バネ定数を算出すると $1.7 \times 10^{4} \mathrm{~N} / \mathrm{m}$ であった。この值は, B-3 試験体で算出したものであ り, $6.25 \mathrm{~Hz}$ が 1 次固有振動数であるものの $30 \mathrm{~Hz}$ 程度までブロー ドな共振特性を示していた。また, 実際に試験体上で足踏みをして みると, 質量も大きいため不安定な感覚ではなかった。一方, 遮音 対策をすれば, 防振ゴムを $25 \mathrm{~mm}$ 程度で, 床衝撃音レベル低減量で $7 \mathrm{~dB}$ 程度が可能であると考えられる。

また，B-2，B-3 も床衝撃音レベル低減量で 9〜10 dB の值を示し ており, 前述したように, 高さが $31.5 \mathrm{~cm}$ でも, 試験体 $\mathrm{A}$ と同程度 以上の性能が測定できたことから, 高さを抑える仕様として有効で あろう。

次に，試験体に，防振ゴムを設置しないで，そのまま空洞部分の 中央を加振すると, $125 \mathrm{~Hz}$ 帯域の床衝撃音レベル低減量がー19〜$13 \mathrm{~dB}$ であった。また, 同様に 250〜 500 Hz 帯域の床衝撃音レベル 低減量もー20〜-14 dB であった。これらは, 遮音層として仕切り 板を設けた A-11〜13 についても, 効果がないことから, まずは防振 対策が重要なことがわかった。

\section{5. まとめ}

本報では，小規模保育所を対象として，重量床衝撃音の対策方法 について基礎的検討を行った。今回の実験では, 限られた設置期間, 低予算で抑えられることを想定して, 市販品 (畳付収納家具) を用い て検討を行った。上下階残響室を用い, 標準重量床衝撃源による床 衝撃音レベル低減量の測定を行った結果, 以下の内容が明らかにな った。

(1)畳付収納家具を用いて, 適切な防振を行い，かつ収納部分に仕切 り板を入れるような遮音対策を併せれば，63 Hz 帯域の床衝撃音 レベル低減量で最大 $14 \mathrm{~dB}$ の性能向上が実現できた。

(2)防振ゴムのバネ定数を小さくすることで, 遮音対策をしなくても， $63 \mathrm{~Hz}$ 帯域の床衝撃音レベル低減量で $5 \mathrm{~dB}$ 以上が可能であると考 えられる。

(3)本研究で用いた試験体 A，B のサイズであれば，高さが $31.5 \mathrm{~cm}$ 程度でも，(1)，(2)と同様な結論が得られる可能性を示した。

(4)本研究で用いた試験体を防振せずに, そのまま利用すると, 遮音 対策をしても， $125 \mathrm{~Hz}$ 帯域の床衝撃音レベル低減量がー19〜-13 $\mathrm{dB}$ であった。

また，具体的な仕様と，重量床衝撃音レベル低減量を表 1,2 にま とめることができた。

今後は，本報の結果を応用して，保育空間にどのように畳付収納 家具を平面的に設置していくかというような具体的な建築設計の提 案についても, 実際の建築物を用いて検討を行っていく予定である。 また, 市販品 (畳付収納家具) を改良した検討だけでなく, 本研究 が発展していけば, 小規模保育所の設置に伴い, 実施されるリフォ 一ムの際などに，どのような仕様の床仕上げ構造を工事すれば，重 量床衝撃音の低減効果が見込まれるのかを提示することも可能とな ると考えられる。

\section{謝辞}

本研究の一部は, 日本大学理工学部の助成及び JSPS 科研費 16H03274 の助成を受けたものである。

\section{参考文献}

1)全国小規模保育協議会 : 小規模保育白書 2016 年版, 2016.3

2) 小規模認可保育所における対象年齢の拡大，2017 年 6 月特区法成立, http://www. kantei. go. jp/jp/singi/tiiki/kokusentoc/menu/hoiku. html 3)富田隆太, 岡庭拓也, 大瀧友多, 阿部今日子：研究目的と実験概要 一保育 施設の床衝撃音対策に関する研究 その 1 -, 日本音響学会 2019 年春季研 究発表会講演論文集, pp. 651-654, 2019.3

4)岡庭拓也, 冨田隆太, 大瀧友多, 阿部今日子：畳付収納家具のサイズ変化と 仕様変化の考察 一保育施設の床衝撃音対策に関する研究 その $2-$, 日本 音響学会 2019 年春季研究発表会講演論文集, pp.655-658, 2019.3

5)Tomita R., Okaniwa T., Otaki Y., Abe K.: Experimental Study on Practical Control of Floor Impact Sound for Nursery Schools, INTER-NOISE 2019, the 48th International Congress and Exhibition on Noise Control Engineering, 1374, pp.1-10, 2019.6

6)Inaba,N., Sato M.: The Study for Sectional Space Consider from Children's Behavior in Nursery Space, Journal of Architecture and Planning, Vol.83, No.754, pp.2283-2290, 2018.12 (in Japanese) 稲葉直樹, 佐藤将之: 幼児の行動様態からみた保育空間の断面計画に関す る考察, 日本建築学会計画系論文集, 83 巻, 754 号, pp.2283-2290, 2018.12 7)文部科学省 : 学校保健統計調査, 令和元年度, 2020.3

[2020 年 5 月 7 日原稿受理 2020 年 7 月 20 日採用決定］ 